\title{
The Influence of Multimedia Teaching on Modern Daily Ceramic Design Course
}

\author{
Dong Cheng ${ }^{1, a}$ and Hui $\mathrm{Li}^{1, \mathrm{~b}}$ \\ ${ }^{1}$ College of Science and Art, Jingdezhen Ceramic University \\ 531070948 @qq.com, 710309089@qq.com
}

\begin{abstract}
Keywords: Multimedia teaching; Modern daily ceramic design teaching research; Serving multiple purposes
\end{abstract}

\begin{abstract}
With the improvement of living standards, people have put forward higher and higher requirements for the design of modern household ceramics. Whether in performance design or structural design, it has put forward higher requirements for the teaching of modern daily ceramic design. The integration of multimedia teaching method can effectively enhance the efficiency of teaching, the computer aided design technology into the curriculum of modern ceramic design may improve the efficiency of ceramic production and quality and enhance students' interests in learning, fully staffed.
\end{abstract}

\section{Introduction}

Teaching of multimedia teaching, also called the modern media or computer assisted instruction, refers to in the teaching process, according to the characteristics of the teaching goal and the teaching object, through the teaching design, rational selection and use modern teaching media, and organic combination with traditional teaching means, participation, the whole teaching process in a variety of media information to students, to form a reasonable teaching process structure, to optimize the teaching effect.[1]Compared with ordinary teaching method, the teaching means more intuitive and to be able to break through the visual space limitation, highlight the key points of teaching and the teaching difficulty, more convenient for students to understand abstract concepts and grasp. From the concrete performance advantages, more graphic audio-visual and multimedia teaching, also more dynamic, interactive, can reflect the teaching concept and teaching process, to make the students more involvement. At the same time, the teaching method can also create the situation of teaching reflection, which is conducive to the formation of new teaching cognition and the better cultivation of students' exploration and creation ability. At the same time, the teaching methods of repeatability and specific relatively serious, convenient for different level students development level teaching, using teaching software of large amount of information and the large capacity, expand teaching space and time, improve the efficiency of teaching. Above all, the author thinks that multimedia teaching can be incorporated into the modern ceramic design curriculum teaching and effectively improve teaching means, in addition, enhancing the teaching effect of this course, optimization of teaching methods, teaching effect of getting twice the result with half the effort.

\section{Improving Teaching Methods}

A prominent feature of multimedia teaching is its strong integration and rich form of information organization. Using it to expand the traditional teaching means can effectively improve the practical effect of teaching. In the course of modern ceramic design, the integration of multimedia teaching can improve curriculum of educational, scientific, artistic and creative, strengthen the students as the main body of teaching engagement. In terms of specific improvement methods, multimedia teaching can be used to carry out collaborative teaching by setting up stratified teaching method in modern daily ceramic design teaching design. Specifically, is to let the teacher according to the different learning ability and level of class teaching object segmentation, form study groups, each group members of the requirements in the knowledge structure and learning potential and skills to 
master level are almost the same, if necessary can take advantage of the test in the form of a quantitative assessment, a more scientific grouping. Groups success, teachers according to the actual circumstance of different groups of students in digital media interactive courseware, encourage students on the basis of courseware teaching make full use of other ceramic production and design of tools and equipment, modern ceramic design practice training, and ask the students, the training process to record video information back to the multimedia teaching management system, in order to reference for teaching reflection of late have credentials, so as to improve teaching quality and teaching effect.

\section{Enhance Teaching Effect}

At the beginning of the industrial design is the concept of ceramic design, from the original classical style to later after the development of intuitive design and experience design, the concept of modern ceramic design more tend to innovation and change, on the one hand, is a high-tech materials into unceasingly, on the other hand is the personalized design of blessings. In this paper the focus of modern ceramic design as an example, the current direction of the ceramic design, through the systematic approach to more reflects the concept of integrated design of the system, especially emphasize to grasp the relationship between product design factors of integrity, comprehensive, calls for optimization design method of intuition thinking and the organic combination of rational design thinking, rather than unilateral, isolation of design object. In such a design method, the embodiment of rational thinking is to accurately grasp the parameter data of the design object. Such as in the $3 \mathrm{~d}$ structure design of ceramic products, ceramic products of precision analysis of $3 \mathrm{~d}$ structure design, and the design of three view drawing and rendering as precisely as possible show students before, to some extent, can improve students for master degree of modern ceramic design. This is a very important aspect in the teaching process of this course and also an important aspect to reflect the teaching effect. The use of multimedia teaching technology can better help teachers to achieve this. In three view drawing and rendering, using Photoshop those programs, Auto CAD, SolidWorks, 3 on3dmax, Unity, and After Effect, Zbrush and so on. Such as teaching teachers can advance to be part of teaching to carry on the fine production, and then in the process of class, by 360。 Rotate the way, enlarge each design effect in front of students, and mark all design parameters in detail, so as to facilitate students to understand and master, so as to enhance the learning effect.

\section{Optimize Teaching Methods}

The teaching method refers to the details of the teaching method, and refers to the specific activity state in the teaching process and the actual form of the teaching activity.[2]It not only includes the methods adopted by teachers to complete teaching tasks, but also includes the basic teaching principles that teachers and students should abide by in the process of teacher-student interaction. In strengthen the interaction between teachers and students link, multimedia teaching can better use of digital media technology using the cross-platform engine search way of interaction makes teachers of modern ceramic design teaching courseware has the ability to publish to multiple systems, so as to extend the teaching platform, enhance the interaction between teachers and students of time and space, and to enhance students' interest in learning, improve the level of students, help them to have a variety of ceramic modeling of innovation ability and design ability. From this level, the extension of multimedia teaching can achieve teaching, make modern ceramic design teaching become more three-dimensional, objectively promoted the modern ceramic design teaching mode shift, can say, put into modern ceramic design teaching, multimedia teaching is a try, combining modern science and technology and art to improve the course teaching mode and teaching means in the future to lay the theoretical foundation.[3] 


\section{Conclusion}

To sum up, the author thinks that modern daily ceramic design is a traditional and modern subject field. The tradition is because ceramic design object carrier is old, the modern is because the development of ceramic design has been innovating and evolving with the development of The Times and the society. So, for such a course teaching, we should set out from the development trend of modern education, information technology and the application of multimedia technology actively into the teaching of the course design, through the teacher's guidance and the auxiliary, make modern ceramics for daily use can open up a new way to design teaching.

\section{References}

[1] Jiang Rong, on the application of multimedia technology in English teaching [J], education, $2002(3):$ p26-p27

[2] Hu Zhengxiang, on the orientation of biology teaching activities in junior middle school [J], teaching research of curriculum materials (education research), 2008 (7) :56-57

[3] Guo wei, application research of digital interaction technology in the teaching of ceramic modeling design $[\mathrm{J}]$, master's thesis of Beijing university of technology, 2013.05.01

[4] Shizhao N, Zheng W, Wangmo P, Yuan N, Peng L. Big Data Prediction of Durations for Online Collective Actions based on Peak's Timing [J]. Physica A: Statistical Mechanics and its Applications, 2018, 55: 130-139. 